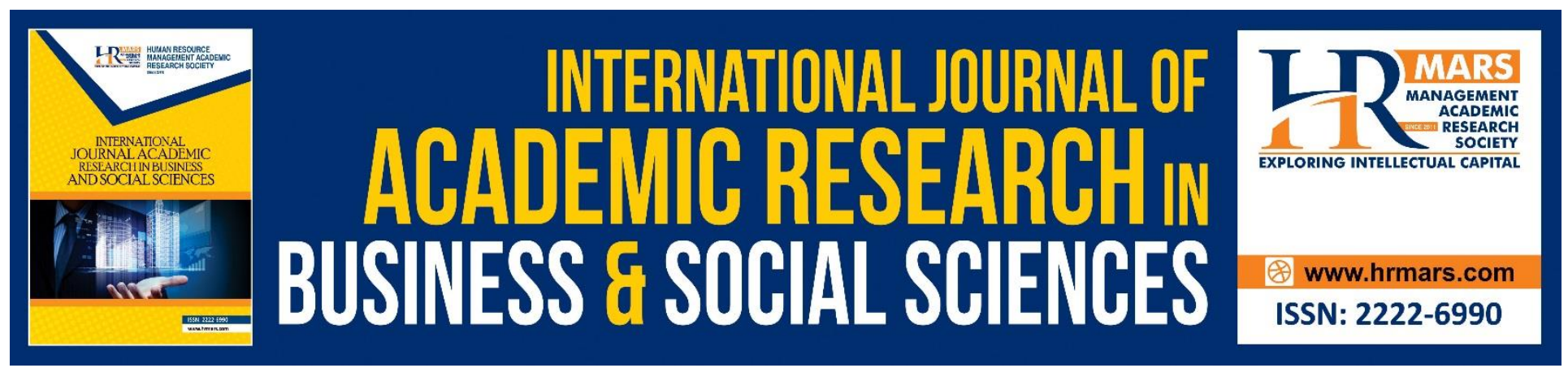

\title{
Legal Issues Relating to Online Transaction: Special Reference to Children Product Safety in Malaysia
}

Farhanin binti Abdullah Asuhaimi, Zuhairah Ariff Abd Ghadas, Nur Amani Pauzai, Khairun-Nisaa Asari

To Link this Article: http://dx.doi.org/10.6007/IJARBSS/v9-i3/5699

DOI: $\quad 10.6007 /$ IJARBSS/v9-i3/5699

Received: 01 Feb 2019, Revised: 21 Feb 2019, Accepted: 14 March 2019

Published Online: 29 March 2019

In-Text Citation: (Asuhaimi, Ghadas, Pauzai, \& Asari, 2019)

To Cite this Article: Asuhaimi, F. binti A., Ghadas, Z. A. A., Pauzai, N. A., \& Asari, K.-N. (2019). Legal Issues Relating to Online Transaction: Special Reference to Children Product Safety in Malaysia. International Journal of Academic Research in Business and Social Sciences, 9(3), 392-400.

Copyright: (C) 2019 The Author(s)

Published by Human Resource Management Academic Research Society (www.hrmars.com)

This article is published under the Creative Commons Attribution (CC BY 4.0) license. Anyone may reproduce, distribute, translate and create derivative works of this article (for both commercial and non-commercial purposes), subject to full attribution to the original publication and authors. The full terms of this license may be seen

at: http://creativecommons.org/licences/by/4.0/legalcode

Vol. 9, No. 3, 2019, Pg. 392 - 400

http://hrmars.com/index.php/pages/detail/IJARBSS

JOURNAL HOMEPAGE

Full Terms \& Conditions of access and use can be found at http://hrmars.com/index.php/pages/detail/publication-ethics 


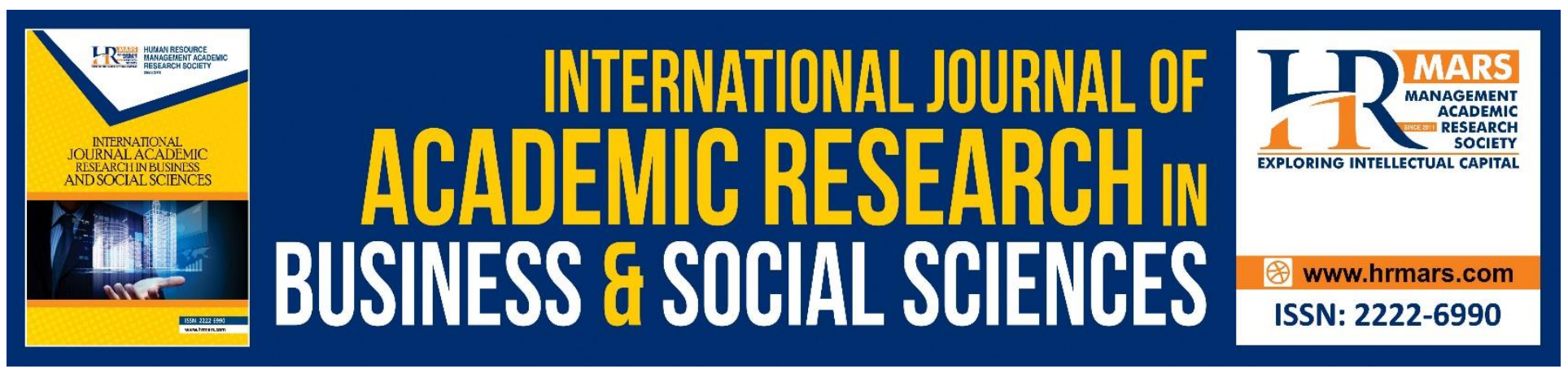

\title{
Legal Issues Relating to Online Transaction: Special Reference to Children Product Safety in Malaysia
}

\author{
Farhanin binti Abdullah Asuhaimi
}

Faculty of Law and International Relations, 21300, Kuala Terengganu, Terengganu, Malaysia

Zuhairah Ariff Abd Ghadas

Faculty of Law and International Relations, 21300, Kuala Terengganu, Terengganu, Malaysia

Nur Amani Pauzai

Faculty of Law and International Relations, 21300, Kuala Terengganu, Terengganu, Malaysia

\section{Khairun-Nisaa Asari}

Faculty of Law and International Relations, 21300, Kuala Terengganu, Terengganu, Malaysia

\begin{abstract}
All children's products are subject to a set of federal safety rules, called children's product safety rules. It is important to classify the product to identify correctly the set of children's product safety rules applicable to the product. As for the online transactions, there is a federal agency called the Federal Trade Commission (FTC) which is responsible to regulate e-commerce activities, including use of commercial emails, online advertising and consumer privacy. In Malaysia, there is no specific law which governs both online transaction and children product safety. The general laws applicable for online transaction are the Electronic Commerce Act 2006, Contracts Act 1950, and Sale of Goods Act 1957 whilst the general law regulating children product safety would be the Consumer Protection Act 1999. This paper discuss the general laws which are applicable in Malaysia related to online transaction of children product and to highlight the legal issues on product safety which arises or might arises due to the current regulatory framework. This paper adopts the statutory analysis and doctrinal analysis research methodology.
\end{abstract}

\section{Introduction}

Electronic Commerce is often interpreted as being just Internet commerce. According to Oxford English Dictionary, electronic commerce means the buying and selling of goods and services, or the transmitting of funds or data, over an electronic network, primarily the Internet. These business 
transactions occurs either business to business, business to consumer, consumer to consumer or consumer to business. Normally, the terms electronic commerce and electronic business are often used interchangeably in the same concept. In a simple word, according to Naemah and Roshaslizawati (2012), e-commerce can be defined as any commercial transactions between the parties which are done electronically. Meanwhile, product safety is a term used to describe policies designed to protect people from risks associated with thousands of consumer products they buy and use every day. In order to safeguard the consumer, the Parliament has enacted certain standards to ensure the products sold are up to the regulated standard. This is important to avoid any manipulation and fraud by the seller as to gain benefit from the product they sell.

\section{Laws on Electronic Commerce in Malaysia}

In Malaysia, there are different laws under different ministries jurisdiction which regulate electronic commerce. The main legislation is Electronic Commerce Act 2006 (ECA) under the jurisdiction of the Ministry of Domestic Trade, Cooperatives and Consumerism. It is an Act to provide for legal recognition of electronic messages in commercial transactions, the use of electronic messages to fulfil legal requirements and to enable and facilitate commercial transaction through the use of electronic means and other matters connected therewith. The application of the Act extends to private electronic commercial; transactions including commercial transactions by the Federal and State Governments.

Besides that, Contracts Act 1950 also plays an important role in the formation of a basic contract through electronic means. Section 2 of the Act defines the terms offer, acceptance, consideration, agreement, contract, void and voidable. The Act also discusses on the requirements of a valid contract where there must be offer from offeror, acceptance by the offeree, consideration between parties and also intention to create legal relations from all contracting parties. Further, the Act also covers on the competency of a person to enter into a contract and the importance of free consent in a contract.

Sales of Goods Act 1957 is also one of the important Act in electronic commerce whereby the Act governs activities of selling goods either online or offline to any consumers as there is neither restrictions for the sale of goods over Internet in the Act, nor that the Act lay down any prerequisites to be fulfilled before an offer for sale of goods can be made. Goods in this Act include all moveable and immovable property as stated in Section 2 of the Act. This Act however, only covers contracts of sale of goods in Peninsular Malaysia only.

Consumer Protection Act 1999 is a piece of legislation enacted with the main objective to provide protection for consumers in the contract. Its purposes are to promote industry responsiveness to consumer requirements, consumer confidence in quality of service, widespread of access to services and affordability of services o Malaysians. Eventhough initially it is not applicable to e-commerce, however after the amendment in 2007, it includes e commerce. 
Personal Data Protection Act 2010 on the other hand, provides a regulatory framework for the processing of personal data in commercial transactions including electronic commerce and business transactions. The Act provides for provisions to combat credit card fraud, identity theft and selling of personal data without customer consent, and to build consumer confidence.

In addition, Malaysia has also developed a set of laws that regulates activities that take place in the cyberspace generally. These cyber laws include Digital Signature Act 1997, Communication and Multimedia Act 1998 and Communication and Multimedia Commission Act 1998. There is also Commission set up as a regulator for all cyberspace activities. Among Malaysian Communication and Multimedia Commission's function is to provide protection for consumers in the information, technology communications and multimedia industries generally. However, there is no single regulatory framework which governs all issues in cyber activities and protects the e consumers.

\section{Laws on Product Safety in Malaysia}

Mandatory information standards are introduced to ensure that consumers are provided with important details of a product to enable them to make appropriate personal choices. Information standards require suppliers to give consumers prescribed information when they purchase specified goods for example, ingredient labelling for cosmetics, labelling for tobacco products and care labelling for clothing and textile products. While information standards may be safety related, they need not be. In Malaysia, there are several legislations aimed for the protection of e-consumer in commercial trade relates to the issue of quality of goods and defective products which include the Consumer Protection Act 1999, the Sale of Goods Act 1957 and the Contracts Act 1950. Compare to other two legislations, Consumer Protection Act 1999 mentioned the issue related to safety product in a more detail discussion. The Act stated that the goods or class of goods become prohibited goods if they have caused or likely to cause injury to person or authority or is unsafe. The consequence of the above declaration are; the prohibited goods will be recalled, the supply or offer to supply goods will be stopped, the advertisement of the prohibited goods will be stopped the characteristic or circumstance that renders them unsafe will be disclosed to public, the prohibited goods will be repaired or replaced or refund the value of the prohibited goods to the buyer

Meanwhile, the main online reference for product safety is Malaysian Consumer Product safety website named as MyStandard. The website is developed to help businesses and consumers obtain information regarding consumer product safety in particular goods and services under the purview of the Ministry of Domestic Trade, Co-operatives and Consumerism (MDTCC). It allows users to access the services provided for compliance to mandatory standards as governed by MDTCC. Besides, users may also obtain the latest information and developments on consumer product safety through this website.

The Department of Standards Malaysia is the national standardisation and accreditation body in Malaysia which functioned. to foster and promote standards, standardisation and accreditation as a means of advancing the national economy, promoting industrial efficiency and development, benefiting the health and safety of the public, protecting the consumers, facilitating domestic and 
international trade and furthering international cooperation in relation to standards and standardisation. Malaysian Standards are developed through consensus by committees which comprise of balanced representation of producers, users, consumers and others with relevant interests, as may be appropriate to the subject in hand.To the greatest extent possible, Malaysian Standards are aligned to or are adoption of international standards.

Approval of a standard as a Malaysian Standard is governed by the Standards of Malaysia Act 1996 (Act 549) and the standards are reviewed periodically. The use of Malaysian Standards is voluntary except in so far as they are made mandatory by regulatory authorities by means of regulations, local by-laws or any other similar ways. The Department of Standards appoints SIRIM Berhad as the agent to develop Malaysian Standards. The Department also appoints SIRIM Berhad as the agent for distribution and sale of Malaysian Standards. There are two categories of product safety law in Malaysia; which are general safety regime and specialised safety regime. Part II of Consumer Protection Act 1999 covers the general safety requirement; where it stated that all products (goods and services) supplied, offered or advertised must be safe. The kind of standard expected by the consumer in this category must be the reasonable standard of safety by a reasonable consumer depends on the nature of goods or services offered.

On the other hand, specialized regime is more towards hazardous products such as food, drugs and cosmetics, medical devices, automotive and parts, electrical or electronic equipment, communication devices, pesticides, toys and many more. It is the responsibility of the regulators to oversee and enforce specific specific law governing the products; for example, Ministry of Health is responsible for medicines product, Energy Commission of Malaysia is responsible for electrical goods; and Ministry of Agriculture is responsible for pesticides.

\section{Product Safety Related to Children}

Children's products are subject to a set of federal safety rules, called children's product safety rules. Determining how your product is classified enables you to identify correctly the set of children's product safety rules applicable to your product. The USA law defines a "children's product" as a consumer product designed or intended primarily for children 12 years of age or younger. There are several factors need to be taken into consideration in determining whether a consumer product can be classified as children product or not. Below are the factors as laid down by the USA:

a. A statement by the manufacturer about the intended use of the product, including a label on the product, if such statement is reasonable.

b. Whether the product is represented in its packaging, display, promotion, or advertising as appropriate for use by children 12 years of age or younger.

c. Whether the product is commonly recognized by consumers as being intended for use by a child 12 years of age or younger.

In Malaysia, however, no such requirements were highlighted, and even no interpretation was given to the phrase. It is believe that the same interpretation and requirements are adapted to Malaysian situation. Malaysian government encourages the Malaysian exporters to make their products more 
competitive by complying with the United States' consumer product safety requirements. Manufacturers need to ensure that their products comply with safety rules known as children's product safety rules. Exporters and testing lab personnel alike were briefed on lead limits, new crib rule, testing and certification requirements as well as typical hazards and defects associated with furniture, during a seminar helmed by representatives from the United States Consumer Product Safety Commission (CPSC). For this reason, manufacturers and importers have to test their products for compliance, which can be done via first party test or third party test. First party test is carried out by manufacturers themselves while third party test is done by testing labs or CPSC-accepted testing labs and the results will be compiled in a certificate after the test. The first party tests have to be renewed every year while third party tests are to be renewed every two years. The children products here can be classified as foods and non-foods. Non-foods here can be further classified into several parts such as apparel, furniture, toys, and many more.

There are few incidents where the products were recall due to the dangerous effect to the children. European Union has issued 188 recall notices since 1st Jan 2017 until March 2017 in the children, toy, electrical appliances and household chemical product categories alone, with toys accounting for $67 \%$ of all the recalls. Slightly over $90 \%$ of all these recalls were categorised as a serious risk.

Glue containing higher than the permitted level of chloroform, pacifiers with straps posing strangulation risks to babies and toddlers, electric bread makers posing fire risks, toys with a high level of phthalates (hormone disruptor) and chargers without double insulation are among the products that have been recalled from the EU market. To date, the EU rapex (European Union Rapid Alert System) has recorded 450 recall notices across all general consumer product categories (excluding food, drugs, medical devices and vehicles).

Quite often, the Malaysian Association of Standards Users (Standards Users) brings these matters to the attention of the relevant authorities in this country but we often do not hear from them on the safety status of these or similar products here said Prof Datuk Dr Marimuthu Nadason in a newspaper reported in 2015 and 2017. He also further stated that among the minimum roles of consumer protection authorities, according to the UN Guidelines for Consumer Protection (UNGCP), are to put in place the appropriate policies to ensure that if manufacturers or distributors become aware of unforeseen hazards after products are placed on the market, they should notify the relevant authorities and, as appropriate, the public without delay. Member States should also consider ways of ensuring that consumers are properly informed of such hazards and that policies are in place to recall it and replace or modify it, or substitute another product for it. If it is not possible to do this within a reasonable period of time, the consumer should be adequately compensated. He also commented that the existence of MyStandard website, even though highlight this issue publicly, however there seem to be limited efforts were taken to safeguard consumers on this issue as the sites recall notices are only up to October 2016. Because of the lack of a holistic approach to product safety in Malaysia, there are just too many regulators from different ministries for one category product; thus lead confusion to the consumers. The consumers here are often going for Internet to search for the answers and given false information normally. Besides, Malaysia also lack of facilities 
where it does not equipped to carry out comparative testing on the scale done by organisations like Which? in Britain and CHOICE in Australia. Moreover, the cost of testing is too expensive and increasing in Malaysia. Malaysia has tested toys, food, cosmetics, instant noodles, sauces, bottled water and tableware by spending several hundreds of thousand ringgit since 2008. Reviews of child care products and toothpastes were also made and the reports were distributed to relevant agencies.

Thus, it is important that all the agencies with consumer protection roles apply best practices in product safety management and recalls (or corrective action) and better manage responses and communication with consumers on issues related to product safety to ward off scandals, myths and fake news. Large scale recalls such as the defective airbags case should have provided valuable lessons to the relevant agencies to improve recalls and product safety management.

\section{Incidents of Product Safety in Other Countries}

A big crisis happened in China from early September 2008 when there is an increased incidence of kidney stones and renal failure among infants. After the investigation was done, the cause of the incidence happened was traced to the contamination of infant formula with melamine. The incidence killed at least 3 babies and 11 others suspected deaths. 51,900 babies were hospitalized for the same issue and the other 294,000 were sick.

Investigations showed that melamine had been deliberately added to diluted raw milk to boost its apparent protein content. The addition of melamine can lead to an incorrectly high protein reading. Because melamine is cheap and easily accessible, there is an economic incentive for its (illegal) addition. Because of the incidence, national reputation of the republic was severely damaged, the international trade was disrupted, the Minister was removed and the senior provincial officials were dismissed. Melamine is listed as a high production volume chemical. The main use of melamine is in the synthesis of melamine formaldehyde resins for manufacture of laminates, plastics, coatings, commercial filters, glues and adhesives, and some dishes and kitchenware. As a result, Malaysia took several steps to secure the consumers in Malaysia by banned all the imports infant milk products from China, imposed Level 6 Examination (Auto Rejection) on all infant formula milk products from China through the Food Safety Information System of Malaysia, Extended the same examination to include milk and milk products from China, imposed restrictions on imports of confections containing milk or milk as an ingredient which includes chocolates, milk and white chocolates and other foods that may contain milk imported in China.

Other than that, there is also incident of recall of toys products in United States where the toys which were tainted with thick coat of glossy paint, was loaded with 5,000 ppm lead, a potent developmental neurotoxicant with no known safe exposure level. The high lead levels were detected during a routine inspection, the Consumer Product Safety Commission (CPSC) issued a recall, the first for a leadcontaminated toy in 2007. Lead-triggered toy recalls were rare, but not unheard of in the United States, with just a handful issued in the last decade. Eventually, nearly 130,000 Elite Operations units, made by a Hong Kong company called Toy Century Industrial and imported by Toys R Us, would be recalled. In a typical year, the recall would have barely ruffled the $\$ 22$ billion U.S. toy industry, which 
sells 3 billion units annually. The toy industry ramped up its inspections for lead, and found that high levels were a lot more common than they had assumed. By the year end, 42 recalls involving nearly 6 million toys had been issued because of excessive lead levels. Lead-contaminated toys became one of the biggest environmental health stories of recent times. It was shocking to think of children being poisoned while playing, and by lead no less, a toxic metal that consumers assumed had been purged from products long ago.

\section{Issues on Product Safety in E-Commerce}

There is a need for the consumer and seller to have knowledge on the product safety before enter into any contract as the transaction is made electronically without any chance of see the real product or touch it. The seller must prescribe the products specifically; as to the material used, the use of the products, and other relevant information. The buyer also has to observe the caveat emptor rule and must aware of all the relevant information before enter into any contract.

\section{Conclusion}

It is the responsible of every level of person to cater this kind of issue from being more rampant as it is deals with the health of our children. The manufacturer has the duty to have a thorough examination or test on the products before it come out to the store. Besides, the distributor also has the responsibility to have the clear status of the product before it is distributed to any other place. The profit gain should be put aside when it relates to the safety of the human being. The Government and other related agencies have the duties to check on the latest information on the status of the products and enforce certain statutory regulations to deal with this issue. Besides that, the most important person is the buyer or the consumer, who need to be updated on the issues of product recall by relying on the authentic source.

\section{Corresponding Author}

Farhanin Abdullah Asuhaimi, Faculty of Law and International Relations, Universiti Sultan Zainal Abidin, 21300, Kuala Terengganu, Terengganu

\section{References}

Amin, N., \& Mohd Nor, R. (2012). An Overview of E-Consumer Protection in Sale of Goods Contracts in Malaysia. International Conference on Information Society.57-58

Beamish, P.M., \&Bapuji,H.(2008).Toy Recalls and China: Emotion vs. Evidence.Management and Organizational Review, 4(2), 197-209

Bruckman, A. (1997). Moose Crossing: Construction, community, and learning in a networked virtual world for kids (Doctoral dissertation). Retrieved from

http://www.static.cc.gatech.edu/ asb/thesis/

Maniam, T. V. (2012). Product Safety in Malaysia.Workshop APEC Product Safety Incidents Information Sharing System-APEC PSIISS. 
Mohd Nor, R. \& Amin, N. (2015).The Issue of Quality of Goods: E-Consumer Protection in Malaysia.Journal of Education and Social Sciences, 2, 88-92.

Product Safety Standard. (2014). Ministry of Domestic Trade, Co-operatives and Consumerism. Retrieved October 3, 2017, from https://mystandard.kpdnkk.gov.my/mystandard_portal2014/index.php?r=column/cfive\&id=66

Shotton, M. A. (1989). Computer addiction? A study of computer dependency. London, England: Taylor \& Francis.

Wilsom, F. E. (n.d). Product Safety Legislation and Implementation Issues in Asia Pacific. Retrieved from http://citeseerx.ist.psu.edu/viewdoc/download?doi=10.1.1.564.1926\&rep=rep1\&type=pdf 